\title{
Performance of Sunflower as Influenced by Establishment Technique and Weed Management
}

\author{
Soumen Bera*, Sibajee Banerjee and Chaitan Soren
}

Department of Agronomy, Faculty of Agriculture, Bidhan Chandra Krishi Viswavidyalaya, Mohanpur, Nadia, West Bengal-741252, India

*Corresponding author

\begin{tabular}{|c|}
\hline \\
\hline $\begin{array}{l}\text { Sunflower, } \\
\text { Pendimethalin, } \\
\text { Butachlor, Micropot } \\
\text { Technique }\end{array}$ \\
\hline Article Info \\
\hline $\begin{array}{l}\text { Accepted: } \\
22 \text { April } 2018 \\
\text { Available Online: } \\
10 \text { May } 2018\end{array}$ \\
\hline
\end{tabular}

\section{A B S T R A C T}

Field experiments were conducted during rabi seasons of 2015 and 2016 at Teaching Farm, College of Agriculture, Extended Campus of BCKV, Burdwan, West Bengalto find out the effect of different establishment techniques and weed management practices in sunflower. The experiment was laid out in split plot design with four replications. Main plot treatment consisted of two establishment methods, viz. $\mathrm{E}_{1}$ : Conventional sowing and $\mathrm{E}_{2}$ : Micro pot technique. Three weed management methods, viz. $\mathrm{W}_{1}$ : pre-emergence application of pendimethalin @1.0 kg/ha followed by hand weeding on 21 days after sowing or transplanting (DAS/DAT), $\mathrm{W}_{2}$ : pre-emergence application of butachlor @1.5 $\mathrm{kg} / \mathrm{ha}$ followed by hand weeding on $21 \mathrm{DAS} / \mathrm{DAT}$ and $\mathrm{W}_{3}$ : Farmer practice (hand weeding at $21 \mathrm{DAS} / \mathrm{DAT}$ ) included in the sub plot treatments. Weed spectrum of the experimental field consisted of three groups of weeds like prominent weed species observed in experimental site were grasses: Cynodon dactylon, Dactyloctaneum aegyptium, Digitaria sanguinalis, Eleusine indica, Echinochloa colona etc. Sedge: Cyperus esculentus, Cyperus rotundus, Fimbristylis littoralis etc. Broadleaf: Alternantherasessilis, Commelina benghalensis, Digera arvensis, Eclipta alba etc. It was observed that micropot technique and pre-emergence application of pendimethalin $1.0 \mathrm{~kg} / \mathrm{ha}$ followed by hand weeding at 21 DAS/DAT can keep the weed density and weed biomass below the economic threshold level and increase the productivity of sunflower.

\section{Introduction}

Sunflower (Helianthus annuus L.) is an important oilseed crop of India and a major source of vegetable oil in the world. India accounted for $3.26 \%$ (1044 thousand MT) of total world sunflower production in 2009 and the average sunflower productivity (580 $\mathrm{kg} / \mathrm{ha}$ ) in India was lower than the world average (1341 kg/ha) (FAO, 2010). Among several constraints in sunflower production, weed infestation is one of the major factors for loss in yield. Weeds which emerge and become established during early stages of sunflower growth can be very competitive and reduce the sunflower yield potential significantly. Enormous loss of nutrients due to uncontrolled weed growth (Sumathi et al., 2009) reduced the seed yield of sunflower up to an extent of $64 \%$. Thus, timely weed control is essential for optimizing the yields of sunflower (Pannacci et al., 2007). Delayed 
monsoon and short winter is a severe problem in rabi sunflower production in West Bengal. Sunflower is an oilseed crop with rising demand day by day. Due to high soil moisture after late harvesting of kharif paddy farmers are compelled to sow sunflower in the month of January resulting poor yield of the crop. High yield of the crop may be obtained by sowing the crop in early December. Therefore, special nursery technique for sunflower is essential so that farmers can sow their seeds in proper time for normal yield. So this can be achieved by sowing the seeds in micropot before harvesting of paddy and transplanting them in the main field just after harvesting of kharif paddy without tillage or with tillage if possible. This technology can utilize the entire residual soil moisture which is one of the primary objectives of this technology. Therefore, the present study was undertaken to identify effective and economical weed management options for sunflower by studying the effect of establishment technique and weed management practices on weed flora and seed yield of rabi sunflower.

\section{Materials and Methods}

Field experiments were conducted during rabiseasons of 2015 and 2016 at Teaching Farm, College of Agriculture, Extended Campus of BCKV, Burdwan, West Bengal. The soil of the experimental farm is sandy loam in texture. The experiment was laid out in split plot design with four replications. Main plot treatment consisted of two establishment methods, viz. $\mathrm{E}_{1}$ : Conventional sowing and $\mathrm{E}_{2}$ : Micro pot technique. Three weed management methods, viz. $W_{l}$ : preemergence application of pendimethalin @ 1.0 $\mathrm{kg} / \mathrm{ha}$ followed by hand weeding on 21 days after sowing or transplanting (DAS/DAT), $W_{2}$ : pre-emergence application of butachlor @1.5 $\mathrm{kg} / \mathrm{ha}$ followed by hand weeding on 21 DAS/DAT and $W_{3}$ : Farmer practice (hand weeding at $21 \mathrm{DAS} / \mathrm{DAT}$ ) included in the sub plot treatments. The sunflower hybrid seed 'DRSH-l' was sown on $60 \times 30 \mathrm{~cm}$. Except establishment techniques and weed management, other management practices were followed as and when necessary.

In conventional sowing, the seeds were dibbled in the on a well tilled field at the desired depth. Whereas in micropot technique, a special nursery bed was developed with equal amount of soil and organic matter mixture at the end of November. 15 days old seedling were carefully uprooted and transplanted in the main field.

Weed management was done as per the treatment. For manual weeding treatments, one hand weeding were given at 21 DAS/DAT. Herbicide treated plots were applied with pendimethalin and butachlor @ $1.0 \mathrm{~kg} / \mathrm{ha}$ and $1.5 \mathrm{~kg} / \mathrm{ha}$, respectively as preemergence on 3 DAS/DAT followed by a hand weeding on 21 DAS/DAT.

Weed density and biomass were recorded following standard protocol. All other yield attributing characters were recorded following standard methods. The grain yield was recorded at the time of harvest. The data were subjected to statistical analysis by analysis of variance method (Gomez and Gomez, 1984). As the error mean squares of the individual experiments were homogenous, combined analysis over the years were done through unweighted analysis. Here, the interaction between years and treatments were not significant.

\section{Results and Discussion}

Weed flora of the experimental field during the cropping period primarily composed of grasses, sedge and broad-leaved weeds. The dominant weed species were: Grass: Cynodon dactylon, Dactyloctaneum aegyptium, Digitaria sanguinalis, Eleusine indica, 
Echinochloa colona, Panicum repens, Paspalum conjugatum etc. Sedge: Cyperus esculentus, Cyperus rotundus, Fimbristylis littoralis etc. Broadleaf: Alternanthera sessilis, Commelina benghalensis, Digera arvensis, Eclipta alba, Lindernia ciliate, Ludwigia octovalvis, Oldenlandia diffusa, Parthenium hysterophorus, Phyllanthus niruri, Physalis minima, Mecardonia procumbens, Sphaeranthus indicus, Hemigra phishirta, Scoparia dulcis, Spilanthes paniculata, Coronopus didymus, Trianthem aportulacastrum, Stellaria media, Polygonum aviculare, Peperomia pellucida etc.

Both establishment technique and weed management methods significantly influenced the weed density and biomass at 25 and 50 DAS/DAT (Table 1). Significantly less weed density and weed biomass were observed with pre-emergence application of pendimethalin $1.0 \mathrm{~kg} / \mathrm{ha}$ followed by hand weeding on 21 DAS/DAT during crop growth period. Yield attributes and seed yield was significantly influenced by establishment techniques and weed management methods (Table 2).

Pre-emergence application of pendimethalin $1.0 \mathrm{~kg} / \mathrm{ha}$ followed by one hand weeding on 21 DAS/DAT resulted in recording bigger capitulum with more seeds per capitulum and test weight of sunflower. Between the establishment technique, micropot technique recorded significantly higher seed yield (3.839 t/ha) of sunflower than conventional establishment technique. Among weed management treatments pre-emergence application of pendimethalin $1.0 \mathrm{~kg} / \mathrm{ha}$ followed by one hand weeding on 21 DAS/DAT recorded significantly highest seed yield (3.728 t/ha) which was followed by preemergence application of butachlor @ 1.5 $\mathrm{kg} / \mathrm{ha}$ followed by hand weeding on 21 DAS/DAT and twice hand weeding. Treatment combination pre-emergence application of pendimethalin $1.0 \mathrm{~kg} / \mathrm{ha}$ followed by one hand weeding on 21 DAS/DAT in combination with micropot technique $\left(\mathrm{E}_{2} \mathrm{~W}_{1}\right)$ recorded significantly highest seed yield (3.984 t/ha) which was closely followed by $\mathrm{E}_{2} \mathrm{~W}_{2}, \mathrm{E}_{1} \mathrm{~W}_{1}$.

In respect of NPV (Table 2), the highest value was obtained with the treatment combination $\mathrm{E}_{2} \mathrm{~W}_{1}$ (2.12) which were closely followed by the treatment $\mathrm{E}_{2} \mathrm{~W}_{2}$ (1.98). Therefore, application of pendimethalin in combination with micropot technique is more promising than laborious, time consuming, costly and back-breaking hand weeding combined with conventional establishment technique.

Among the predominant grassy weed flora Digitaria sanguinalis shares highest position (23\%) followed by Eleusine indica (21\%), Echinochloa colona (17\%) etc. In case of sedge weed flora, Cyperus rotundus occupied significantly highest share i.e., $72 \%$ whereas Alternanthera sessilis (14\%), Commelina benghalensis (12\%), Digera arvensis (11\%), Eclipta alba (9\%) are the predominant broad leaf weed flora present in sunflower experimental field.

Significantly Lower weed density and weed biomass were recorded in micro pot technique than conventional methods in both the years due to wider spacing, less competition and deposition of weed seeds in the upper layer of the soil. Pre-emergence herbicides gave effective control of weeds by inhibiting the germination of the weed seeds and also killing the emerging weeds at the early stages.

Treatments received micro pot technique increased the yield attributes such as diameter and weight of the capitulum and number of seeds per capitulum of sunflower. This might be due to more amount of nutrient uptake consequently resulting in better related growth attributes. 
Table.1 Effect of establishment technique and weed management practices on total weed density and weed biomass in sunflower

\begin{tabular}{|c|c|c|c|c|c|c|}
\hline \multirow[t]{2}{*}{ Treatment } & \multicolumn{3}{|c|}{$\begin{array}{l}\text { Total weed density }\left(\text { no. } / \mathbf{m}^{2}\right) \\
\text { (Pooled) }\end{array}$} & \multicolumn{3}{|c|}{$\begin{array}{c}\text { Total weed biomass }\left(\mathrm{g} / \mathrm{m}^{2}\right) \\
\text { (Pooled) }\end{array}$} \\
\hline & 25DAS & 50DAS & 75DAS & 25DAS & 50DAS & 75DAS \\
\hline \multicolumn{7}{|c|}{ Establishment technique } \\
\hline \multirow[t]{2}{*}{$\mathbf{E}_{1}$} & 5.11 & 9.18 & 11.77 & 10.35 & 32.70 & 52.98 \\
\hline & (25.67) & $(84.00)$ & (139.11) & & & \\
\hline \multirow[t]{2}{*}{$\mathbf{E}_{2}$} & 5.00 & 8.84 & 11.13 & 10.02 & 30.81 & 49.07 \\
\hline & $(24.56)$ & (77.89) & $(124.33)$ & & & \\
\hline SEm $( \pm)$ & 0.03 & 0.04 & 0.05 & 0.05 & 0.30 & 0.78 \\
\hline $\operatorname{LSD}(\mathbf{P}=0.05)$ & 0.13 & 0.19 & 0.22 & 0.22 & 1.37 & 3.51 \\
\hline \multicolumn{7}{|c|}{ Weed management } \\
\hline \multirow[t]{2}{*}{$\mathrm{W}_{1}$} & 4.92 & 8.50 & 10.56 & 9.80 & 28.13 & 40.40 \\
\hline & $(23.67)$ & (71.83) & $(111.00)$ & & & \\
\hline \multirow[t]{2}{*}{$\mathbf{W}_{2}$} & 5.03 & 8.86 & 10.99 & 10.03 & 30.50 & 47.63 \\
\hline & $(24.83)$ & $(78.00)$ & (120.33) & & & \\
\hline \multirow[t]{2}{*}{$\mathbf{W}_{3}$} & 5.23 & 9.67 & 12.81 & 10.73 & 36.63 & 65.03 \\
\hline & $(26.83)$ & (93.00) & $(163.83)$ & & & \\
\hline SEm $( \pm)$ & 0.03 & 0.06 & 0.08 & 0.09 & 0.32 & 0.99 \\
\hline LSD $(P=0.05)$ & 0.10 & 0.20 & 0.25 & 0.29 & 1.00 & 3.06 \\
\hline \multicolumn{7}{|c|}{ Establishment technique $\times$ Weed management } \\
\hline \multirow[t]{2}{*}{$\mathbf{E}_{1} \mathbf{W}_{1}$} & 4.95 & 8.65 & 10.78 & 9.86 & 29.03 & 41.27 \\
\hline & $(24.00)$ & (74.33) & (115.67) & & & \\
\hline \multirow[t]{2}{*}{$\mathbf{E}_{1} \mathbf{W}_{2}$} & 5.08 & 9.06 & 11.34 & 10.13 & 31.67 & 50.20 \\
\hline & $(25.33)$ & (81.67) & $(128.00)$ & & & \\
\hline \multirow[t]{2}{*}{$\mathbf{E}_{1} \mathbf{W}_{3}$} & 5.31 & 9.82 & 13.20 & 11.07 & 37.40 & 67.47 \\
\hline & $(27.67)$ & $(96.00)$ & (173.67) & & & \\
\hline \multirow[t]{2}{*}{$\mathbf{E}_{2} \mathbf{W}_{1}$} & 4.88 & 8.36 & 10.34 & 9.73 & 27.23 & 39.53 \\
\hline & $(23.33)$ & $(69.33)$ & $(106.33)$ & & & \\
\hline \multirow[t]{2}{*}{$\mathbf{E}_{2} \mathbf{W}_{2}$} & 4.98 & 8.65 & 10.64 & 9.93 & 29.33 & 45.07 \\
\hline & (24.33) & (74.33) & (112.67) & & & \\
\hline \multirow[t]{2}{*}{$\mathbf{E}_{2} \mathbf{W}_{3}$} & 5.15 & 9.51 & 12.43 & 10.40 & 35.86 & 62.60 \\
\hline & (26.00) & (90.00) & (154.00) & & & \\
\hline $\operatorname{SEm}( \pm)(\mathbf{E} \times \mathbf{W})$ & 0.04 & 0.09 & 0.11 & 0.13 & 0.46 & 1.40 \\
\hline $\operatorname{SEm}( \pm)(\mathbf{W} \times E)$ & 0.05 & 0.09 & 0.10 & 0.12 & 0.48 & 1.39 \\
\hline $\begin{array}{c}\text { LSD }(\mathbf{P}=0.05) \\
(\mathrm{E} \times \mathbf{W})\end{array}$ & 0.14 & 0.28 & 0.35 & 0.41 & 1.41 & 4.32 \\
\hline $\begin{array}{c}\text { LSD }(\mathbf{P}=\mathbf{0 . 0 5}) \\
(\mathbf{W} \times \mathbf{E})\end{array}$ & 0.17 & 0.29 & 0.36 & 0.40 & 1.76 & 4.89 \\
\hline
\end{tabular}

Figures in parentheses are original values which were subjected to square root transformation.

$\mathrm{E}_{1}$-Conventional sowing, $\mathrm{E}_{2}$ - Micro pot technique, $\mathrm{W}_{1^{-}}$Pendimethalin $(\mathrm{PE})+$ one hand weeding at $21 \mathrm{DAS}, \mathrm{W}_{2^{-}}$ Butachlor $(\mathrm{PE})+$ one hand weeding at $21 \mathrm{DAS}, \mathrm{W}_{3^{-}}$- Farmer practice (Hand weeding at $21 \mathrm{DAS}$ ) 
Table.2 Effect of establishment technique and weed management practices on yield attributes and yield of sunflower

\begin{tabular}{|c|c|c|c|c|c|c|}
\hline Treatment & $\begin{array}{l}\text { Capitulum } \\
\text { diameter }(\mathrm{cm}) \\
\text { (Pooled) }\end{array}$ & $\begin{array}{c}\text { Capitulum } \\
\text { weight (g) } \\
\text { (Pooled) }\end{array}$ & $\begin{array}{l}\text { No. of seeds/ } \\
\text { capitulum } \\
\text { (Pooled) }\end{array}$ & $\begin{array}{c}\text { Seed yield } \\
\text { (t/ha) } \\
\text { (Pooled) }\end{array}$ & $\begin{array}{c}\text { Stalk yield } \\
\text { (t/ha) } \\
\text { (Pooled) }\end{array}$ & $\begin{array}{c}\text { NPV } \\
\text { (Pooled) }\end{array}$ \\
\hline \multicolumn{7}{|c|}{ Establishment technique } \\
\hline$E_{1}$ & 13.93 & 53.17 & 931.50 & 1.735 & 3.521 & 1.67 \\
\hline $\mathbf{E}_{2}$ & 14.43 & 54.90 & 945.37 & 1.924 & 3.839 & 1.94 \\
\hline $\operatorname{SEm}( \pm)$ & 0.06 & 0.22 & 2.90 & 0.033 & 0.038 & \\
\hline $\operatorname{LSD}(\mathbf{P}=0.05)$ & 0.25 & 0.99 & 13.06 & 0.150 & 0.172 & \\
\hline \multicolumn{7}{|c|}{ Weed management } \\
\hline $\mathbf{W}_{1}$ & 14.60 & 56.85 & 983.90 & 1.937 & 3.851 & 2.01 \\
\hline $\mathbf{W}_{2}$ & 14.30 & 53.90 & 930.95 & 1.890 & 3.728 & 1.85 \\
\hline $\mathbf{W}_{3}$ & 13.65 & 51.35 & 900.45 & 1.662 & 3.462 & 1.57 \\
\hline $\operatorname{SEm}( \pm)$ & 0.07 & 0.24 & 3.07 & 0.036 & 0.047 & \\
\hline $\operatorname{LSD}(\mathbf{P}=0.05)$ & 0.20 & 0.75 & 9.47 & 0.111 & 0.144 & \\
\hline \multicolumn{7}{|c|}{ Establishment technique $\times$ Weed management } \\
\hline $\mathbf{E}_{1} \mathbf{W}_{1}$ & 14.3 & 55.80 & 978.60 & 1.852 & 3.718 & 1.89 \\
\hline $\mathbf{E}_{1} \mathbf{W}_{2}$ & 14.1 & 52.90 & 925.10 & 1.792 & 3.607 & 1.71 \\
\hline $\mathbf{E}_{1} \mathbf{W}_{3}$ & 13.4 & 50.80 & 890.80 & 1.562 & 3.238 & 1.42 \\
\hline $\mathrm{E}_{2} \mathrm{~W}_{1}$ & 14.9 & 57.90 & 989.20 & 2.022 & 3.984 & 2.12 \\
\hline $\mathbf{E}_{2} \mathbf{W}_{2}$ & 14.5 & 54.90 & 936.80 & 1.988 & 3.848 & 1.98 \\
\hline $\mathbf{E}_{2} \mathbf{W}_{3}$ & 13.9 & 51.90 & 910.10 & 1.762 & 3.686 & 1.72 \\
\hline $\begin{array}{c}\operatorname{SEm}( \pm) \\
(\mathbf{E} \times W)\end{array}$ & 0.08 & 0.35 & 4.35 & 0.051 & 0.066 & \\
\hline $\begin{array}{c}\operatorname{SEm}( \pm) \\
(\mathbf{W} \times \mathbf{E})\end{array}$ & 0.09 & 0.36 & 4.59 & 0.053 & 0.068 & \\
\hline $\begin{array}{c}\text { LSD }(\mathbf{P}=0.05) \\
(\mathrm{E} \times \mathrm{W})\end{array}$ & 0.28 & 1.06 & 13.40 & 0.157 & 0.203 & \\
\hline $\begin{array}{c}\text { LSD }(\mathbf{P}=\mathbf{0 . 0 5}) \\
(\mathbf{W} \times \mathbf{E})\end{array}$ & 0.33 & 1.29 & 16.74 & 0.194 & 0.235 & \\
\hline
\end{tabular}

$\mathrm{E}_{1}$-Conventional sowing, $\mathrm{E}_{2}$ - Micro pot technique, $\mathrm{W}_{1}$ - Pendimethalin $(\mathrm{PE})+$ one hand weeding at $21 \mathrm{DAS} / \mathrm{DAT}$, $\mathrm{W}_{2^{-}}$Butachlor $(\mathrm{PE})+$ one hand weeding at $21 \mathrm{DAS} / \mathrm{DAT}, \mathrm{W}_{3}$ - Farmer practice (Hand weeding at $21 \mathrm{DAS} / \mathrm{DAT}$ )

Significantly higher yield attributes and yield was recorded in pre-emergence application of pendimethalin $1.0 \mathrm{~kg} / \mathrm{ha}$ followed by one hand weeding on 21 DAS/DAT. This might be due to reduced weed density and biomass of all categories of weeds during critical period of crop weed competition thus resulting in better translocation of assimilates from source to sink during post anthesis period (Sumathi et al., 2010).

Combining pendimethalin followed by hand weeding with micropot technique is more economically viable and acceptable due to less cost of cultivation along with better net return resulting from higher seed production It was concluded that micropot technique and pre-emergence application of pendimethalin $1.0 \mathrm{~kg} / \mathrm{ha}$ followed by hand weeding at 21 DAS/DAT can keep the weed density and weed biomass below the economic threshold level and increase the productivity of sunflower.

\section{Acknowledgement}

The authors are thankful to Mr. Deb Sharma, Mr. Dharma Pramanick and Mrs. Lakshmi Mandi for their cooperation during the field experimentation and data collection. 


\section{References}

FAO (Food and Agriculture Organisation) 2010. FAO STAT. Crops Production, Food and Agriculture Organisation of United Nations, Rome, Italy. (http:/ /faostat.fao.org/site/291/default.aspx).

Gomez, K. A., and Gomez, A. A., 1984. Statistical Procedures for Agricultural Research, 2nd edn. Singapore: John Wiley \& Sons

Legha P. K., Malik, R. K., and Faroda, A. S., 1992. Weed management in Kharif sunflower (Helianthus annuus L.). Crop Research 5(2): 376-379.

Pannacci, E., Graziani, F., and Covarelli, G.,
2007. Use of herbicide mixtures for preand post-emergence weed control in sunflower (Helianthus annuus). Crop Protect. 26: 1150-1157.

Sumathi, V., Rao, D. S. K., Subramanyam, D., and Reddy, D. S., 2009. Effect of planting pattern and weed management on nutrient uptake and economics of rabi sunflower and its associated weeds. Ind. J. Weed Sci. 41: 65-70.

Sumathi, V., Subramanyam, D., Koteswara Rao, D. S., and Reddy, D. S., 2010. Effect of planting pattern and weed management on weed flora and yield of rabi sunflower. Indian Journal of Weed Science, 42(3\&4): 212-216.

\section{How to cite this article:}

Soumen Bera, Sibajee Banerjee and Chaitan Soren. 2018. Performance of Sunflower as Influenced by Establishment Technique and Weed Management. Int.J.Curr.Microbiol.App.Sci. 7(05): 3193-3198. doi: https://doi.org/10.20546/ijcmas.2018.705.373 